\title{
Bioactive compounds and their their antifeedant activity in the cashew nut (Anacardium occidentale L.) shell extract against Bemisia tabaci, (Gennadius, 1889) (Hemiptera:Aleyrodidae)
}

\author{
Wuye Ria ANDAYANIE ${ }^{1,2}$, Wahidin NURIANA ${ }^{1}$, Netty ERMAWATY ${ }^{3}$
}

Received January 24, 2019; accepted June 10, 2019.

Delo je prispelo 24. januarja 2019, sprejeto 10. junija 2019.

\begin{abstract}
Bioactive compounds and their their antifeedant activity in the cashew nut (Anacardium occidentale L.) shell extract against Bemisia tabaci, (Gennadius, 1889) (Hemiptera:Aleyrodidae)
\end{abstract}

Abstract: The present study was carried out to analyze bioactive compounds and their their antifeedant activityity in the cashew nut (Anacardiaceae) shell extract against Bemisia tabaci. Hexane was used as solvent in the extraction. The result showed that shell extract of total phenolics, flavonoids and tannins were $63.11 \mathrm{mg}$ gallic acid equivalents g-1; $1.79 \mathrm{mg}$ quercetin equivalents $\mathrm{g}^{-1}$; and $16.04 \mathrm{mg}$ gallic acid equivalents $\mathrm{g}^{-1}$, respectively. Gas chromatography mass spectrometry (GC-MS) analyses showed that anacardic acid has the highest concentration $(76.93 \%)$ in the extract. The viscous extract of cashew nut at concentration of $0.75 \%$ was able to inhibit the landing and provided an active role as anti-oviposition on B. tabaci. There were significantly fewer landings than after use of insecticide with imidacloprid active compound at concentration of 0.50 $\%$, after $72 \mathrm{~h}$ of application. Mortalities of B. tabaci caused by extracts with concentration of $1.50 \%$ and $3.00 \%$ were not significantly different after 24 and $48 \mathrm{~h}$ of application. At concentration of $3.00 \%$ there was no phytotoxic effect. The highest mortality of B. tabaci was obtained at concentration of $6.00 \%$. However, concentration of $6 \%$ of extract caused phytotoxic symptoms on soybean leaves.

Key words: cashew nut shell (CNS); Bemisia tabaci; botanical insecticide; antifeedant; antioviposition; soybean.
Bioaktivne spojine v izvlečkih luščin indijskega oreščka (Anacardium occidentale L.) in njihova protiprehranjevalna aktivnost na tobakovega ščitkarja, Bemisia tabaci, (Gennadius, 1889) (Hemiptera:Aleyrodidae)

Izvleček: $\mathrm{V}$ raziskavi so bile analizirane bioaktivne snovi $\mathrm{v}$ izvlečku luščin indijskega oreščka (Anacardium occidentale L.) in njihova protiprehranjevalna aktivnost na tobakovega ščitkarja (Bemisia tabaci). Topilo za ekstracijo je bil heksan. Izvleček luščin je vseboval celokupne fenole $(63,11 \mathrm{mg}$ ekvivalentov galne kisline $\mathrm{g}^{-1}$ ), flavonoide (1,79 mg ekvivalentov kvercetina $\left.\mathrm{g}^{-1}\right)$ in tanine $(16,04 \mathrm{mg}$ ekvivalentov galne kisline $\left.\mathrm{g}^{-1}\right)$. Analiza s plinsko kromatografijo in masno spektroskopijo je pokazala, da je imela anakardična kislina v izvlečku največjo koncentracijo (76,93 \%). Lepljiv izvleček luščin indijskega oreščka je pri koncentraciji $0,75 \%$ preprečil usedanje vrste $B$ tabaci in imel preko tega aktivno vlogo pri preprečevanju izleganja jajčec. Pojavnost škodljivca je bila značilno manjša kot pri uporabi insekticida $\mathrm{z}$ imidaklopridom kot aktivno snovjo v koncentraciji 0,50 \%, 72 ur po uporabi. Smrtnost vrste $B$. tabaci, povzročena $\mathrm{z}$ izvlečkom $\mathrm{v}$ koncentracijah $1,50 \%$ in $3,00 \%$ ni bila po 24 in 48 h uporabe značilo različna. Pri 3, $0 \%$ koncentraciji izvlečka ni bilo nobenega fitotoksičnega učinka. Največja smrtnost vrste $B$. tabaci je bila pri 6,00 \% koncentraciji izvlečka, a je hkrati ta koncentracija povzročila fitotoksične učinke na listih soje.

Ključne besede: luščine indijskega oreščka (CNS); Bemisia tabaci; rastlinski insekticid; antifedant; antiovipozicija; soja

1 Merdeka Madiun University, Department of Agrotechnology, Madiun 63133, Indonesia

2 Corresponding author, e-mail: wuye.andayanie@gmail.com

3 State of Polytechnic of Jember,Department of Agricultural and Production, Jember 68120, Indonesia. E-mail: nettyermawati@yahoo.com 


\section{INTRODUCTION}

One of the main problems in soybean cultivation today is the presence of whitefly ((Bemisia tabaci (Gennadius, 1889) (Hemiptera: Aleyrodidae)). Adults and nymphs suck sap from leaves, phloem feeding, to obtain secrete abundant honeydew which encourages the growth of sooty mold fungus with black coating on the leaf surface. The accumulation of fungi reduces sunlight penetration and the photosynthetic rate (Vieira et al., 2013).

This pest is a viral vector of Cowpea mild mottle virus (CPMMV) and Soybean mosaic virus (SMV). These viruses could be transmitted to the plants by the feeding of infected $B$. tabaci adults. Whitefly vector could decrease soybean yield up to $80 \%$. Resistance information of soybean genotypes to aphid vector has not been much done (Gulluoglu et al., 2010; Sulistyo \& Inayati, 2016; Andayanie et al., 2017). The use of chemical pesticide has been indicated to be excessive by the soybean farmer's. Moreover, the use of chemical is generally not recommended for B. tabaci as the high risk of the toxic residual effect can be hazardous to consumers' health and pest resurgence problem. Recently, B. tabaci was found to be resistant to chemical pesticide (Takahashi et al., 2008). Consequently, botanical insecticides may be potential alternatives of chemical for managing $B$. tabaci, which make them suitable insecticides for organic agriculture.

The cashew nut shells contain several components. Of the raw nut mass, $25 \%$ is liquid. The main components of cashew nut shell (CNSL) are anacardic acid (80-90 \%), cardol (8-10\%) and 2-methyl-cardol (2\%). Cardanol has similar chemical structure with synthetic phenols and among its decarboxylated derivates occurring naturally is anacardic acid (Santos \& Magalhaes, 1999). The anacardic acid is converted into cardanol by thermal decarboxylation. Anacardic acid has antifeedant, arrestant, repellent effects, which affect insect growth and development (Isman, 2006; Tunca et al., 2014; Martinez et al., 2015). However, information about cashew nut shell extract as botanical insecticide against $B$. tabaci are limited. The present study aimed to analyze some of bioactive compounds with antifeedant activity in cashew nut shell extract against $B$. tabaci.

\section{MATERIALS AND METHODS}

\subsection{PLANT MATERIAL FOR PREPARING CASHEW NUT SHELL EXTRACT}

Shells were collected from waste product of cashew nut (Anacardium occidentale L.) processing located in
Wonogiri (Indonesia) which has not been exploited optimally. The shells were removed from the nuts and washed in tap water and then air dried. The dried samples were crushed into pieces and ground to fine powdered form.

\subsection{PREPARATION OF CASHEW NUT SHELL EX- TRACT}

Cashew nut shell was extracted according to the method of Edoga et al. (2006) with slight modification. Extraction of powdered CNS was carried out by percolation method using n-hexane $\left(\mathrm{C}_{6} \mathrm{H}_{14}\right)$ as solvent. Filtrate was evaporated on rotary evaporator at a temperature of $55^{\circ} \mathrm{C} \pm 5$ under low pressure $(550-600 \mathrm{~mm} \mathrm{Hg})$ until obtaining of a brown viscous extract.

\subsection{QUANTIFICATION OF PHYTOCHEMICALS}

\subsubsection{Total phenolic content}

The content of total phenolics of CNS extract was determined by method of Emelike et al. (2017), with slight modification. The sample of CNS extract $(1 \mathrm{mg})$ was dissolved in methanol solution $(1 \mathrm{ml})$. Each sample $(250 \mu \mathrm{l})$ was mixed with $2.5 \mathrm{ml}$ of $10 \%$ Folin-Ciocalteu's reagent by manual shaking for $30 \mathrm{~s}$, then $2.0 \mathrm{ml}$ of $7 \%$ $\mathrm{Na}_{2} \mathrm{CO}_{3}$ was added. The reaction mixture was vortexed for $10 \mathrm{~min}$ and incubated in dark at room temperature for $60 \mathrm{~min}$. The solution was mixed and absorbance was measured against a blank at $750 \mathrm{~nm}$ with an UV visible spectrophotometer. Blank consists of all reagents except the extract. Standard solution of gallic acid was prepared $\left(0.00625-0.1 \mu \mathrm{g} \mathrm{ml}^{-1}\right)$. The concentration of total phenolics was calculated in $\mathrm{mg}$ of gallic acid equivalents per gram (mg GAE. $\mathrm{g}^{-1}$ ) of extract. Each sample of extract was prepared in triplicate.

\subsubsection{Total flavonoid content}

The content of total flavonoids of CNS extract was determined according to the method of Zhiszhen et al. (1999) with slight modification. The sample of CNS extract $(1 \mathrm{mg})$ was dissolved in methanol solution $(1 \mathrm{ml})$. Each sample $(1.0 \mathrm{ml})$ was mixed with $4 \mathrm{ml}$ of distilled water and $0.3 \mathrm{ml}$ of $\mathrm{NaNO}_{2}$ solution $(10 \%)$ was added. After $5 \mathrm{~min}, 0.3 \mathrm{ml} \mathrm{AlCl}$ solution (10\%) was mixed. After another $5 \mathrm{~min}, 2.0 \mathrm{ml}$ of $\mathrm{NaOH}$ solution (1\%) was treated and diluted with distilled water to make up to 10 $\mathrm{ml}$. The solution was mixed and absorbance was measured against a blank at $510 \mathrm{~nm}$ with an UV visible spec- 
trophotometer. Blank consists of all reagents except the extract. Standard solution of quercetin was prepared $\left(2-10 \mathrm{mg} \mathrm{ml}^{-1}\right)$. The content of the flavonoids in extract $\left(\mathrm{mg} \mathrm{ml}^{-1}\right)$ was expressed as mg quercetin equivalents per $\mathrm{g}\left(\mathrm{mg}\right.$ QE. $\left.\mathrm{g}^{-1}\right)$ of extract. Each sample of extract was prepared in triplicate.

\subsubsection{Tannin content}

The content of tannins of CNS extract was determined according to the method of Tambe \& Bhambar (2014) with slight modification. The sample of CNS extract $(1 \mathrm{mg})$ was dissolved in methanol solution $(1 \mathrm{ml})$. Each sample extract $(0.1 \mathrm{ml})$ and $7.5 \mathrm{ml}$ of distilled water were taken in a volumetric flask $(10 \mathrm{ml})$. Then $0.5 \mathrm{ml}$ of Folin-Ciocalteu phenol reagent and $1 \mathrm{ml}$ of $35 \% \mathrm{Na}_{2} \mathrm{CO}_{3}$ solution were added. The volume was made up to $10 \mathrm{ml}$ with distilled water and shaken well. The mixture was incubated in dark for $30 \mathrm{~min}$ at room temperature and absorbance was measured against a blank at $760 \mathrm{~nm}$ with an UV visible spectrophotometer. Blank consists of all reagents except the extract. Standard solution of gallic acid was prepared $\left(2-10 \mathrm{mg} \mathrm{ml}^{-1}\right)$. The concentration of tannins was calculated in $\mathrm{mg}$ gallic acid equivalents per g (mg GAE. $\mathrm{g}^{-1}$ ) of extract. Each sample of extract was prepared in triplicate.

\subsection{IDENTIFICATION BIOACTIVE COMPOUNDS OF CASHEW NUT SHELL}

Identification of bioactive compounds of CNS extract were carried out by gas chromatography-mass spectrometry (GC-MS) GCD $1800 \mathrm{C}$. These compounds were based on NISTO2.L that integrated on GC-MS instruments and the results obtained have been tabulated.

\subsection{REARING OF INSECT}

Soybean (Glycine max "Willis") plants were infested with adults $B$. tabaci in the care cage net. Female adults will lay eggs and hatch into nymph. After $10 \times 24 \mathrm{~h}$, adults of all insect were removed from leaves by opening the cage and shaking the plant. Thereafter, plants were covered with the cage net until adults of insects emerged a sufficient amount on the abaxial parts of soybean leaves.

\subsection{BIOLOGICAL TEST OF ANTIFEEDANT}

Viscous extract of CNS was tested for antifeedant ac- tivity using B. tabaci as bioindicator. The viscous extract was diluted with distilled water to obtain concentration viz., $0.75 \%, 1.50 \%, 3.00 \%, 6.00 \%(\mathrm{w} / \mathrm{v})$. Then $0.50 \mathrm{ml}$ of emulsifier Tween 80 was added to keep the solvent extract homogeneous in water. They were compared with the ability of imidacloprid active compound (Movento Energy 240 SC) and control treatment. The compound is a systemic insecticide that acts as an insect neurotoxin. This insecticide was used at its recommended commercial dose $\left(0.50 \mathrm{ml} \mathrm{l}^{-1}\right)$. Control treatment used distilled water. Each soybean plant, was placed in the cage net and sprayed according to the treatment. After $30 \mathrm{~min}$, the plant was infested with 50 pairs of $B$. tabaci adults of uniform age $(72 \mathrm{~h})$ using a hand aspirator and released into each cage. After another $5 \mathrm{~min}$, the aspirator flask was checked to count $B$. tabaci adults which had died due to handling. The landing of $B$. tabaci on the leaves and mortality were counted at $24 \mathrm{~h}, 48 \mathrm{~h}$ and $72 \mathrm{~h}$ after spraying with three replications. Adults were considered dead when all appendages did not move after touching with brush under a stereo-microscope. Percentage of mortality was corrected and calculated using Sun-Shepard's formula (Puntener, 1981):

$$
\mathrm{P}=\frac{\mathrm{Po} \pm \mathrm{Pc}}{100 \pm \mathrm{Pc}_{\mathrm{c}}} \times 100 \%
$$

Where is the percentage of insect population corrected mortality, is the percentage mortality in treated plot and $\mathrm{Pc}$ is the percentage change in control plot population. The percentage change in control plot population was calculated using the following equation:

$$
\mathrm{Pc}=\frac{\mathrm{Ct}-\mathrm{Co}}{\mathrm{Co}} \times 100 \%
$$

Where is the percentage change in control plot population, is the number of insect in control after treatment and is the number of insect in control plot before treatment. Oviposition response was determined by counting the number of eggs laid for $72 \mathrm{~h}$ on one of the leaves per plant under a stereo-microscope.

\subsection{STATISTICAL ANALYSIS}

Data from the landing, mortality and oviposition of $B$. tabaci adults after application of CNS extract were analyzed according to the study and sample data, with percentage data being subjected to transformation before analyses. To determine mortality and oviposition 
response in each cage, they were subjected to analysis of variance (ANOVA) and the means separated by DMRT test $(p<0.05)$.

\section{RESULTS AND DISCUSSION}

\subsection{YIELD OF CASHEW NUT SHELL EXTRACT}

Extraction of powdered cashew nut shell (1000 g) produced $30.55 \mathrm{~g}$ of a viscous brown liquid. The result of viscous extract with normal-hexane (n-hexane) was $48.83 \%$. Extraction with $n$-hexane can remove oil from cashew seed shells and volatiles, providing a high yield of viscous extract. According to Kusrini \& Ismardiyanto (2003), the cashew nut shell contains $32-37 \%$ of liquid in which the aliphatic side chain of cashew nut shell liquid (CNSL) has the most semi-polar or non-polar compounds.

\subsection{PHYTOCHEMICAL'S CONTENT}

The content of total phenolics was expressed as gallic acid (the standard curve equation:, $\mathrm{R}^{2}=0.9976$ ). Total flavonoids content was expressed as quercetin (the standard curve equation:, $\left.\mathrm{R}^{2}=0.9954\right)$. Total tannins content was expressed as gallic acid (the standard curve equation:, $\mathrm{R}^{2}=0.9981$ ). Results presented in Table 1 show that the average of total phenolics, flavonoids and tannins contents were $63.11 \mathrm{mg}$ GAE. $\mathrm{g}^{-1}, 1.79 \mathrm{mg} \mathrm{QE.g^{-1 }}$ and $16.04 \mathrm{mg} \mathrm{GAE} \mathrm{g}^{-1}$ of CNS extract, respectively.

This study confirms the presence of phytochemicals such as phenolics, flavonoids and tannins in CNS extract.
Measurement of total phenolics, flavonoids and tannins content were obtained by the extracting solvent polarity. It was clear that CNS extracts contained several phenolic compounds. These phenolic compounds have been recognized as an important source of bioactive substances in high concentration. Some authors have found that on the base of solubility of phenolics their high concentration could be obtained using polar solvent for extraction (Mohsen \& Anwar, 2008). Moreover, phenolic compounds are one of the biggest contributors to strong insecticidal activity against B. tabaci (Estrada et al., 2013). The findings of Bagnarello et al. (2009), Silva et al. (2012) and Ul-Haq et al. (2012) stated that the presence of flavonoids and tannins in Tithonia and Toona ciliate M. Roem had role as antifeedants and inhibit the landing $B$. tabaci on the leaves.

\subsection{BIOACTIVE COMPOUNDS}

Bioactive compounds had a molecular mass spectra of $378 \mathrm{~m} / \mathrm{z}(\mathrm{M}+)$. Fragmentation patterns were: 324, $301,278,252,233,211,188,125,149,112,81$ and 41 . The chemical structure of phenolic compounds with C15 aliphatic chains showed the present of several compounds in cashew nut shells. The anacardic acid had the highest concentration (76.93\%), while other compounds amounted to $21.22 \%$, viz. cardol (12.75\%), cardanol $(4.66 \%)$ and 2 - methyl-cardol (3.81\%). These compounds are presented in Table 2.

The anacardic acid had high concentration, up to $76.93 \%$ in CNS extract, as the main peak with retention time $35.138 \mathrm{~min}$. The content of anacardic acid showed the dominant role of bioactive compound in CNS ex-

Table 1: Total phenolics, flavonoids and tannins content of CNS extract

\begin{tabular}{llr}
\hline Parameters & Unit & Total content \\
\hline Phenolic & mg GAE.g ${ }^{-1}$ of extract & 63.11 \\
Flavonoid & mg QE. mg $^{-1}$ of extract & 1.79 \\
Tannin & mg GAE.g ${ }^{-1}$ of extract & 16.04 \\
\hline
\end{tabular}

a) Each value is the average of three replicates; GAE is gallic acid equivalent; $Q E$ is quercetin equivalent.

Table 2: Bioactive compounds of CNS extract

\begin{tabular}{lllr}
\hline Peaks & Retention time $(\mathrm{min})$ & Alleged compound & Concentration $(\%)$ \\
\hline 5 & $35.138^{\text {a) }}$ & Anacardic acid & 76.93 a) \\
7 & 36.425 & Cardol & 12.75 \\
6 & 37.619 & Cardanol & 4.66 \\
8 & 36.226 & 2-Methyl-cardol & 3.81 \\
\hline
\end{tabular}

a) Each value is the average of three replicates. 


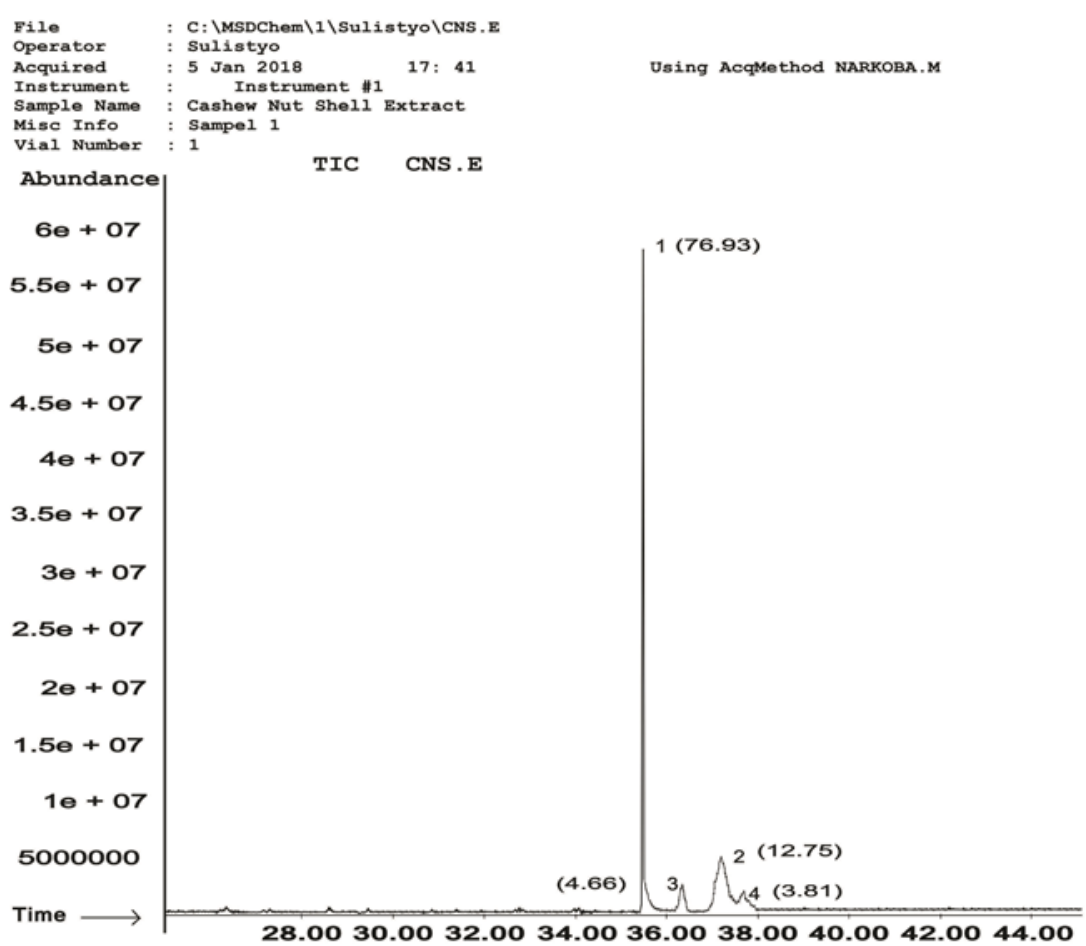

Figure 1: Chromatogrm of CNS extract analyzed using GC-MS

tract. The GC-MS analysis of CNS extract revealed the presence of bioactive compounds (Figure 1).

These results are similar to those reported by Silva et al. (2008) that showed the fragmentation of 329, 285, 259, $229,201,121,175,148,105,91,79$, and 41 with molecular mass of $374 \mathrm{~m} / \mathrm{z}(\mathrm{M}+)$. Rodrigues et al. (2006) reported that CNSL is an essential mixture of 4 phenolic com- pound namely anacardic acid, cardanol, cardol, 2 methyl cardol. Insect repellents and feeding inhibitors (antifeedants) could be explained by LC50: 15.8489 ppm activity, which are important as pesticide (Santos and Magalhaes, 1999; Kusrini and Ismardiyanto, 2003). Cashew nut shell liquid (CNSL) treatments have been reported in delayed larval and pupal periods and deformed larve

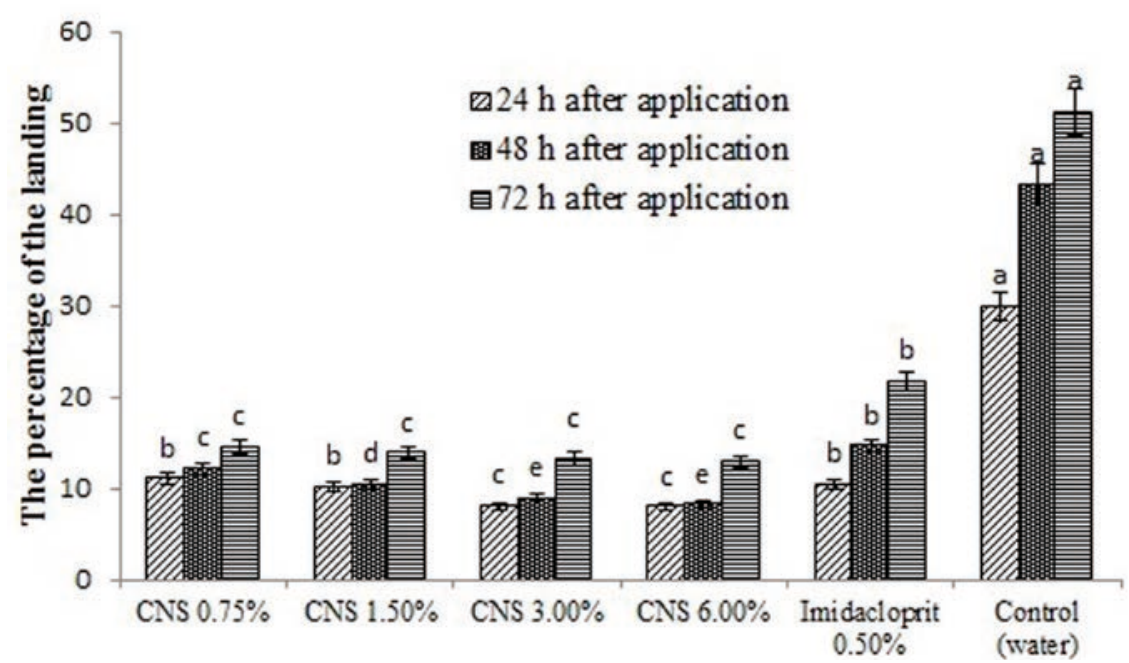

Figure 2: The percentage of the landing of B. tabaci adults on soybean leaves after application of CNS extract. Means followed by the same letter in the same bars, are not significantly different $(P<0.05)$. Abbreviations: CNS (cashew nut shell). 
of Helicoverpa armigera (Hubner, 1808) (Mahapatro, 2011). Moreover, Asogwa et al. (2007) mentioned that the high mortality of termites is caused by a complex mixture of the compounds with anacardic acid in the CNSL. In addition, the extract showed herbicide activity and significantly reduced weeds (Andayanie et al., 2018).

\subsection{THE LANDING OF BEMISIA TABACI}

From the analysis of data in Figure 2, we infer that CNS extract at concentration of $0.75 \%$ was able to inhibit the landing of $B$. tabaci. It has been either shown that extract is also given the same result with concentration $(1.50 \%, 3.00 \%, 6.00 \%)$ and caused significantly fewer landing of $B$. tabaci adult than insecticide with imidacloprid active compound at concentration of $0.50 \%$ after $72 \mathrm{~h}$ application.

Accumulation of secondary metabolites from cashew nut shell extract on leaf surface inhibited the landing of $B$. tabaci and the tissues of leaves contain polyphenol compounds as flavonoids and tannins (causing the antifeedant). This one possibility was caused by expression of feeding deterrence. Regarding their use, $B$. tabaci adults could make contact with deterrent substances on the plant which are able to inhibit their landing. Bagnarello et al. (2009) showed that the number of giant whitefly adult landings were determined by antifeedants activity after application of Tithonia leaf extract. The presence of flavonoids and tannins in Tithonia secondary metabolites had role as antifeedant. Furthermore, extract of Toona ciliata leaves in dichloromethane caused an inhibitory effect on landing of the B. tabaci on tomato leaflets (Silva et al., 2012).

\subsection{MORTALITY AND OVIPOSITION OF BEMISIA TABACI}

The CNS extract at concentration of $0.75 \%$ and insecticide with imidacloprid active compound at concentration of $0.50 \%$ caused mortalities that were not significantly different among treatments $(p<0.05)$ at $24 \mathrm{~h}$ after application. CNS extract at concentration of $0.75 \%$ showed significantly higher mortality of $B$. tabaci than insecticide with imidacloprid active compound at concentration of $0.50 \%$ after 48 and $72 \mathrm{~h}$ application. However, the activity of extract did not differ from CNS extract at concentration of $1.50 \%$ and $3.00 \%$ after 24 and $48 \mathrm{~h}$ application, respectively. The highest mortality was obtained at concentration of $6.00 \%$. In addition, there was significant difference among treatments $(p<0.05)$ at $72 \mathrm{~h}$ after application. Moreover, the treatments of CNS concentrations $(0.75 \%, 1.50 \%, 3.00 \%$ and $6.00 \%)$ demonstrated significantly lower percentages of oviposition activities than those treated with imidacloprid at concentration of $0.50 \%$ and control with water after $72 \mathrm{~h}$ application. However, at concentration of $6 \% \mathrm{CNS}$ extract CNS extract caused phytotoxic symptoms on soybean leaves. The percentage of oviposition was the lowest in CNS extract at concentration of $6.00 \%$, there was significant difference $(p<0.05)$ with CNS extract at concentration of $0.75 \%, 1.50 \%, 3.00 \%$ (Figure 3 ).

Cashew nut shell extract had no capability to kill $B$. tabaci directly but it had an inhibitory effect on landing and staying on the leaves for feeding deterrence. The high mortality of $B$. tabaci adults were caused by the antifeedant active compounds that actively acted as a barrier of feeding deterrence in high enough amounts to protect the plants. In addition, $B$. tabaci would not make contact with plants until the whitefly die from starvation, apparently because the bioactive compound of CNS extract.

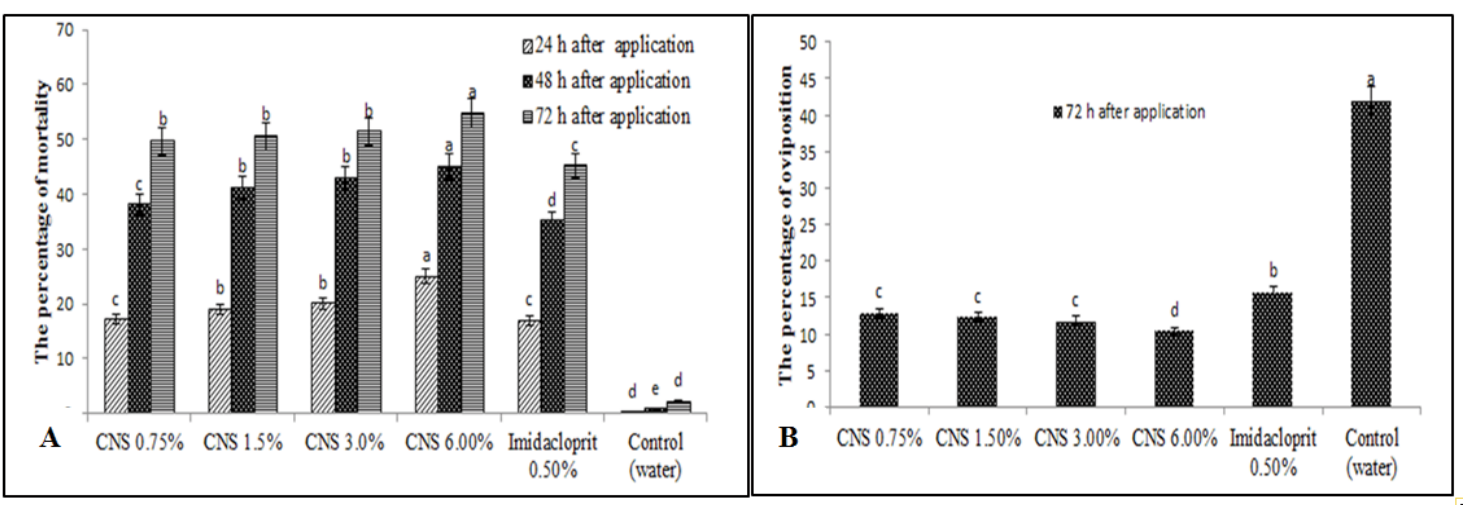

Figure 3: (A) the percentage of mortality at $24 \mathrm{~h}, 48 \mathrm{~h}$ and $72 \mathrm{~h}$ after application of CNS extract (B) the percentage of oviposition at $72 \mathrm{~h}$ after application of CNS extract. 
Although the activity of CNS extract was low at 24 hours after application, its activity increased at 72 hours after application. All the CNS extract tested reduced oviposition of B. tabaci when compared with Imidacloprid and control. However, oviposition depends on many factor including percentage of female mortality and suitable host plant of female imago. Anti-oviposition activity of B. tabaci hs a correlation with feeding repellent in host plant. Newly laid eggs of $B$. tabaci are at the beginning whitish then change brownish. According to the previous results obtained by Flores et al. (2008) and Silva et al. (2012), the antifeedant compounds blocked directly the work of sensory cells to repellent effect and caused dead insects to starve. This statement is in affirmation of the secondary metabolites contents in CNS extract i.e phenolics, among them flavonoids and tannins acted as repellents and cover up the attracting signals on $B$. tabaci. On the other hand, application of CNS extract had a deterrent effect on $B$. tabaci in concentration dependent manner. Antifeedant activity stimulated specific eating repellent nerves of deterrent chemoreceptors in the insect mouth.

\section{CONCLUSION}

This study showed the presence of phenolics, among them flavonoids and tannins in CNS extract. Phenolic compounds contained anacardic acid, cardanol, cardol, 2 methyl cardol. The content of anacardic acid showed the dominant role of this antifeedant active compound in CNS extract. CNS extract with the smallest concentration $(0.75 \%)$ had an active role as antifeedant on $B$. tabaci, as well as with concentration of $3.00 \%$ at $72 \mathrm{~h}$. In concentration of $3.00 \%$, there was no phytotoxic effects on the leaves. Therefore, CNS extract could be developed as a source of botanical insecticide for the B. tabaci control on soybean plant. This will help to reduce the environmental pollution, the problem of cost production and resurgence of insect on farm condition.

\section{REFERENCES}

Andayanie, W.R., Santosa, V., Rahayu, M. (2017). Resistance to Soybean mosaic virus with high yield on F7 soybean lines. International Journal of Agriculture \& Biology, 19(2), 226-232. https://doi.org/10.17957/IJAB/15.0263

Andayanie, W.R., Ermawati, N., Iswati, R. (2018). Use tillage system and botanical herbicide of cashew nut shell extract on losses nutrient and organic matter in the sloping land. Proceedings of the 4th International Symposium on Applied Chemistry 2018. AIP Conf. Proc. 2024, 020018-1-0200186. https://doi.org/10.1063/1.5064304
Asogwa, E.U.,Mokwunye, I.U., Yahaya, L.E., Ajao, A.A. (2007). Evaluation of cashew nut shell liquid (CNSL) as a potential natural insecticide against termites (soldier and worker castes). Research Journal of Applied Science, 2, 939-942

Bagnarello, G., Hilje, L., Banarello, V., Cartin, V., Calvo, M. (2009). Actividad fagodisuasiva de las plantas Tithonia diversifolia y Montanoa hibiscifolia (Asteraceae) sob re adult osdeiinsectoplaga Bemisia tabaci (Homoptera: Aleyrodidae). Revista de Biology Tropical, 57, 1201-1215. https:// doi.org/10.15517/rbt.v57i4.5457

Bernays, E.A., Chapman, R.F. (1994). Host plant selection by phytophagus insect. Contemporary topics in entomology, 2 (pp. 1756-1757). New York (NY): Chapman and Hall. https://doi.org/10.1007/b102508

Edoga, M.O., Fadipe, L., Edoga, R.N. (2006). Extraction of polyphenols from cashew nut shell. Leonardo Electronic Journal of Practices and Technologies, 9, 107-112.

Emelike, N.J.T., Akusu, M.O., Ujong, A.E. (2017). Antioxidant and physicochemical properties of oil extracted from cashew (Anacardium occidentale L) kernels. International Journal of Food Science and Nutrition, 2(6), 122-128.

Estrada, A.C., Angulo, M.G., Argaez, R.B., Sanchez, E.R. (2013). Insecticidal effect of plants extract on immature whitefly Bemisia tabaci Genn. (Hemiptera: Aleyroideae). Electronic Journal of Biotechnology, 16(1), 1-6. doi: 10.2225/vol16issue1-fulltext-6. https://doi.org/10.2225/vol16-issue1fulltext-6

Flores, G., Hilje, L., Mora, G.A., Carballo, M. (2008). Antifeedant activity of botanical crude extract and their fractions on Bemisia tabaci (Homoptera: Aleyrodidae) adults: II. Sechium pittieri (Cucurbitaceae). Revista de Biologia Tropical (Int. J. Trop. Biol.), 56(4), 2115-2129. https://doi. org/10.15517/rbt.v56i4.5782

Gulluoglu, L., Arioglu,H., Kurt, C. (2010). Field evaluation of soybean plan cultivars for resistance to whitefly (Bemisia tabaci Genn.) infestations. African Journal of Agricultural Research, 5(7), 555-560.

Isman, M.B. (2006). Botanical insecticides, deterrents, and repellents in modern agriculture and an increasingly regulated world. Annual Review of Entomology, 51, 45-66. https:// doi.org/10.1146/annurev.ento.51.110104.151146

Kusrini, D., Ismardiyanto, M. (2003). Anacardic acid of cashew nut shell (Anacardium occidentale L.) with cytotoxic activity. Journal of Scientific \& Applied Chemistry, 6(1), 4-6.

Mahapatro, G.K. (2011). Insecticidal activity of cashew nut shell liquid against two Lepidoptera pest. Indian Journal Entomology, 73(2), 121-124.

Martínez, L.C., Plata, R.A., Zanuncio, J.C., Serrao, J.E. (2015). Bioactivity of six plant extracts on adults of Demotis paneivai (Coleoptera: Chrysomelidae). Journal Insect Science, 15(34), 1-5. https://doi.org/10.1093/jisesa/iev021

Mohsen, S.M., Ammar, A.S.M. (2008). Total phenolic content and antioxidant activity of corn lassel extracts. Food Chemistry, 112(3), 595-598. https://doi.org/10.1016/j.foodchem.2008.06.014.

Puntener, W. (1981). Manual for field trials in Plant Protection, Agric. Div, Ciba-Geigy Limited. Basle, Switzerland. p. 205.

Rodrigues, F.H.A., Feitosa, J.P.A., Ricardo, N.M.P.S., Franca, F.C.F., Caroca, J.O.B. (2006). Antioxidant activity of cashew 
nut shell liquid derivatives on the thermal oxidation of synthetic cis-1, 4-polyisoprene. Journal of the Brazilian Chemical Society, 17(2), 265-271. https://doi.org/10.1590/S010350532006000200008

Santos, M.L., Magalhaes, G.C. (1999). Utilisation of cashew nut shell liquid from Anacardium occidentale starting material for organic synthetic: A novel route to lasiodiplodin from cardols. Journal of the Brazilian Chemical Society, 10(1), 13-20. https://doi.org/10.1590/S0103-50531999000100003

Silva, G.C.D.B., Silva, M.A., Vendramim, J.D., Dias, C.T.D.S. (2012). Insecticidal and behavioral effects of secondary metabolites from Meliaceae on Bemisia tabaci (Hemiptera: Aleyrodidae). Florida Entomologist, 95(3), 743-751. https://doi.org/10.1653/024.095.0325

Sulistyo, A., Inayati, A. (2016). Mechanisms of antixenosis, antibiosis, and tolerance of fourteen soybean genotypes in response to whiteflies (Bemisia tabaci). Biodiversitas, 17(2), 447-453. doi:10.13057/biodiv/d170207.

Takahashi, K.M, Filho, E.B., Lourencao, A.L. (2008). Biology of Bemisia tabaci (Genn.) B biotype and parasitism by Encarsia formosa (Gahan) on collard, soybean and tomato plants. Scientia Agricola (Piracicaba, Brazil), 65 (6), 639-642. https://doi.org/10.1590/S0103-90162008000600011
Tambe, V.D., Bhambar, R.S. (2014). Estimation of total phenol, tannin, alkaloid and flavonoid in Hibiscus tiliaceus Linn. Wood extract. Res. and Rev. Journal of Pharmacognosy and Phytochemistry, 2(4), 41-47. https://doi.org/10.5897/ SRE2014.5823

Tunca, H., Kilincer, N., Ozkan, C. (2014). Toxicity and repellent effects of some botanical insecticides on the egg larva parasitoid Chelonus oculator Panzer (Hymenoptera: Braconidae). Scientific Research Essays, 9(5), 106-113. https:// doi.org/10.5897/SRE2014.5823

Ulhaq, I., Ullah, N., Bibi, G., Kanwal, S., Ahmad, M.S., Mizra, B. (2012). Antioxidant and cytotoxic activities and phytochemical analysis of Euphorbia wallichii root extract and its fractions. Iran Journal of Pharmaceutical Research, 11(1), 241-249.

Vieira, S.S., Bueno, R.C.O.F., Bueno, A.F., Boff, M.I.C., Gobbi, A.L. (2013). Different timing of whitefly control and soybean yield. Ciencia Rural, 43(2), 247-253. doi: https://doi. org/10.1590/S0103-84782013000200009.

Zhishen, J., Mengcheng, Jianming, W. (1999). The determination of flavonoid contents in mulberry and their scavenging effects on superoxide radicals. Food Chemistry, 64(4), 555-559. https://doi.org/10.1016/S0308-8146(98)00102-2 